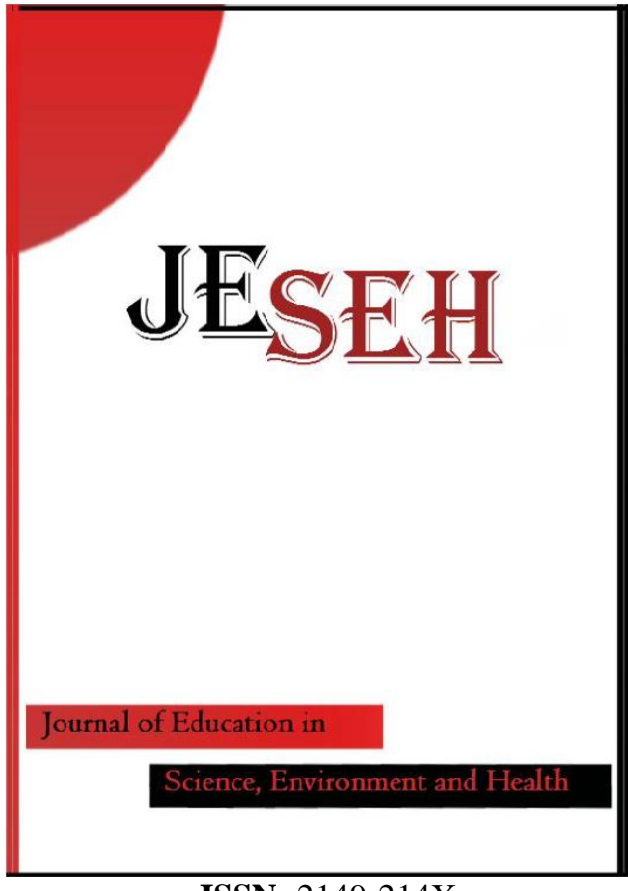

ISSN: $2149-214 \mathrm{X}$

\section{Journal of Education in Science,} Environment and Health

www.jeseh.net

Using Digital Games in Technology Oriented STEM Education: The Examination of the Students' Game Designs

\section{Ismail Donmez ${ }^{1}$, Murat Tekce ${ }^{2}$, Serihan Kirmit $^{3}$}

${ }^{1}$ Mus Alparslan University

${ }^{2}$ Cebeci Middle School

${ }^{3}$ Sehit Huseyin Gultekin Science and Art Center

To cite this article:

Donmez, I., Tekce, M. \& Kirmit, S. (2020). Using digital games in technology oriented STEM education: The examination of the students' game designs. Journal of Education in Science, Environment and Health (JESEH), 6(2), 77-91. DOI:10.21891/ jeseh.669097

This article may be used for research, teaching, and private study purposes.

Any substantial or systematic reproduction, redistribution, reselling, loan, sub-licensing, systematic supply, or distribution in any form to anyone is expressly forbidden.

Authors alone are responsible for the contents of their articles. The journal owns the copyright of the articles.

The publisher shall not be liable for any loss, actions, claims, proceedings, demand, or costs or damages whatsoever or howsoever caused arising directly or indirectly in connection with or arising out of the use of the research material. 


\title{
Using Digital Games in Technology Oriented STEM Education: The Examination of the Students' Game Designs
}

\author{
Ismail Donmez, Murat Tekce”Serihan Kirmit
}

\begin{tabular}{|c|c|}
\hline Article Info & Abstract \\
\hline Article History & $\begin{array}{l}\text { The purpose of this research is to examine the contents of the representations } \\
\text { that students used while producing digital games in the scope of STEM }\end{array}$ \\
\hline Received: & education. The descriptive survey model among the other quantitative research \\
\hline 10 May 2019 & methods has been used. Within the scope of this purpose, 300 games from the \\
\hline $\begin{array}{l}\text { Accepted: } \\
\text { 01 December } 2019\end{array}$ & $\begin{array}{l}\text { competition arranged throughout Turkey with the name of "I encode my } \\
\text { game" have been examined in terms of different variables. Checklists were } \\
\text { created by the researchers to analyze the data. In these checklists, mental }\end{array}$ \\
\hline Keywords & $\begin{array}{l}\text { structures (abstract, concrete, mixed and simple content), the use of violent } \\
\text { content, the characters, the subject of the game, the type of points, the }\end{array}$ \\
\hline Digital games & dominant colors were examined. Findings show that boys were more \\
\hline STEM & interested in the game production process than girls while the counselors were \\
\hline Education technology & all females. it has been found that students intensively used concrete elements \\
\hline Scratch & and gave more importance to the educational technologies such as \\
\hline Competition & educational-instructional games and quiz shows. Students used human figures, \\
\hline Game design & $\begin{array}{l}\text { animals, objects and fantasy characters as the protagonists in their games. As } \\
\text { for the representation of the human figures, it is seen that the proportions of } \\
\text { boys and girls were equal. Digital games in technology-oriented STEM } \\
\text { education promote students to join the production process on a large scale. At } \\
\text { further researches, it is thought that providing students with educational } \\
\text { content like game encoding is highly important. }\end{array}$ \\
\hline
\end{tabular}

\section{Introduction}

In the past, it was preferable to play games at real playgrounds, homes, or streets with real friends, but nowadays computer games, computerized virtual activities, or online games have become much more preferable (Horzum 2011). With the rapid advancement of the technology, the traditional game concept has changed, and a new concept called "'digital game" has been created with the fact that digital tools has become an indispensable part of daily life. Increasing consumer interests towards the digital games and thus emerging market of digital games have shown itself in Turkey as well as all over the world. Increasing of popularity video games, make this video games current issue for educational games on the agenda.

Educational games are planned and purposeful games that provide the achievement of the objectives determined during the education process, develop knowledge and skills, and prepare the environment for reinforcing the previous learning (Coşkun, 2012). Çankaya and Karamete (2008) regard the importance of education technologies today as the result of the rapid development of technology and computer and regard as the new quest for solving the problems of education and training. Students demand and play with the digital educational content and thus loving to learn (İşman 2005). While the literature based on educational play is growing, a systematic review of the effectiveness of this new technology is still inadequate. Regardless of the complexity of a game and apart from the fact that technological integration of the game is its propulsive force, games could be propelling force in the process of learning for entitled as digital natives to achieve their 21 st century skills.

Shin, Park and Bae (2014) state that the basic skills which the individuals of 21 st century can be obtained through the education of computer and programming. In their study based on the effect of programming on the development of mathematical and technological thinking, Taylor, Harlow and Forret (2010) has found out that the education of programming has an effect on teaching of mathematical subjects, developing problem-solving strategies and improving collaborative, systematic and creative thinking. In digital game-based learning, students are expected to learn by playing educational computer games. Prensky (2001) states that students are willing to be a part of digital game-based learning, and also there are many different types of educational computer games like normal computer games which have a strategy or an action in them, and adds that these computer games 
combining different learning methods with many various types of games provide students with a broader sense of latent learning. Therefore, the students have fun playing these educational digital games and realize that they have learned new things when the game is over.

Educational digital games can be combined with other learning methods and provide a complete learning. Digital games are also classified in different groups. These groups mainly consist of abstract games, meaningful games, meaningless games, and progressive games. (Yenğin, 2010: 114). Mitchell and Smith (2004) differentiate the game types as action games, fighting games, platform games, adventure games, simulation games, modeling games, road games, logical games and math games. The games require that the complex and diverse capabilities should be brought together, focusing on the virtual world, thinking, strategy, planning, and most importantly, interacting with this world. (Bostan and Tingöy, 2015) According to Prensky (2001), a game should have its own rules, goals, objectives, feedback, struggle, interaction, presentation and the story. The rules provide various ways for the players to reach their goal. The goals and objectives create a sense of duty in the players and make them spend their time and effort voluntarily. The feedback tells the players how far they have gone through their goals and provides some returns when the possible situations have changed in response to the players' reactions. Struggle / race / challenge / contrast are the basic problems that need to be dealt with during the game. The users can feel some fear and excitement during the game without facing any danger as in real life. This motivates and allows them to continue and complete the game. As for the interaction, two types of interaction can be mentioned. The first one is the interaction of the players or the computer, which can also be called as feedback. The second one is the social situation that the players create with each other while playing that game. The presentation or story is the subject of the game. The story of the game can be given directly at the beginning or in the course of the game. Many programs or tools can be used in the production of a game. One of the most common used software in primary, middle and high school levels is Scratch.

The Scratch programming platform was intended for the individuals between the age of 8-16 by the Massachusetts Institute of Technology (MIT) Media Laboratory in 2003. However, today, individuals of all ages use this platform. Since its opening to the public in May 2007, the Scratch Web site (http://scratch.mit.edu) has become a lively online community of people sharing, discussing and reinterpreting each other's projects. The users from around the world install more than 1500 new projects to this website every day, and it can be freely used to share and re-mix the source codes. This website's project collection includes video games, interactive stories, science simulations, virtual tours, birthday cards, animated dance competitions and interactive tutorials, which are all programmed in Scratch. Thanks to the interface that does not require any code-writing, users can create projects by dragging the code block from one place to another, and this website also offers a convenience for the newcomers. With more than 40 different language support, the users in more than 150 countries can easily communicate with each other and create collaborative projects (Resnick et al, 2009). Scratch program can also be used to create projects in different courses including the elements of music, pictures, simulations, games, presentations, videos, animations and many other multimedia elements (Çatlak, Tekdal and Baz, 2015).

Scratch has been used to enhance the development of technological fluency of young children at afterschool centers in economically disadvantaged communities (Peppler \& Kafai, 2007) and to teach computer programming concepts in a college-level computer science class (Malan \& Leitner, 2007). Apart from Algorithm and Programming Teaching, some subjects that are difficult to learn in courses such as Mathematics, Science, Foreign Language, Social Studies could be made enjoyable with Scratch projects and these subjects could be taught to students through playing games (Çatlak, Tekdal \& Baz, 2015). Acording to Zhang, Yang, Luan, Yang, \& Chua, (2014), Scratch not only serves as a programme learning tool but also contributes to high-level thinking skills. According to Marcelino, Pessoa, Vieria, Salvador and Mendes (2017), 'Scratch" is the most widely used program in teaching programming at the level of K-12. Çatlak, Tekdal and Baz (2015) suggest that Scratch should also be integrated with other courses besides the course of programming as almost all kinds of multimedia applications could be developed with the use of this programme. Yünkül, Durak, Çankaya and Mısırlı (2017) emphasize that it is important to expand the use of Scratch at the beginner and intermediate level in education programming, and for this program to be included in the curriculum. Yükseltürk and Altınok (2016) state that there are not any alternative methods and methodologies in teaching programming and the number of studies on this subject is very limited. Becta (2001) emphasizes the need for teachers to be involved in the process of educational game design.

In this age of rapid expansion of computer and educational technology, digital games have reached an attractive level. The gaming industry is growing rapidly, reaching millions of players very quickly. Science, technology, engineering and mathematics (STEM) education of digital games is also important for technology-oriented applications. Advancements in educational technology have provided various opportunities for supporting student learning, and they offer unique affordances for complex, integrated STEM learning environments. For example, learning experiences can be expanded to facilitate learning multiple subjects simultaneously. (Yang \& Baldwin, 
2020). STEM learning environment (Lunce, 2006; Smith and Mader, 2017). But what exactly does Technology mean from the concepts that make up STEM? Does it depict an electronic product? Or any product that makes our lives easier? Sivaraj, Ellis \& Roehrig (2019) states that technology has three different meanings in STEM in its systematic literature review: 1. As educational technologies in STEM 2. Engineering product in STEM 3. Includes coding and computer thinking in STEM

Coding and computer thinking in STEM Education; There are various studies in which technology, coding, programming or computer thinking are included in science, engineering and mathematics activities (Swaid, 2015). Examples include designing digital works like websites and video games using applications such as Scratch. Learning and applying programming languages means using digital designs and computer technology in STEM learning process. The inclusion of coding practices into STEM-related practices can be seen as an effective tool "as students develop their design skills". In engineering applications involving computer thinking; for example, students develop mechatronic smartphone / Bluetooth-controlled 3D-design mobile vehicles, Kim et al. (2013) how to use robotics in engineering design based courses. Students using programming devices such as Raspberry $\mathrm{Pi}$ and Arduino combining programming and engineering applications can be given as examples. Interactive, immersive games that involve science, mathematics, engineering, and technology STEM learning (Lemke, 2013). The following sub-problems have also been dealt with in this research while searching an answer for the question "which contents do the middle school students make use of in STEM educational technologies while developing their digital game coding skills?',

- What are the contents that students use while producing digital games?

What are the types in the games that students encode?

What are the types of the characters that students use in the games they encode?

What are the objects that students use on their interfaces in the games they encode?

What are the awards students using in the games they encode?

What colors students use intensively in the games they encode?

\section{Method}

Descriptive survey model, which is one of the quantitative research methods, has been used in this study. The general survey method has been used in the research process. The general screening models are screening arrangements applied on the whole universe or on a group of samples gathered from it in order to make a general judgement about the universe that consists of many elements (Karasar, 2003:79). Relational screening models in this group are between two and more variables. Since it is used for research models aiming to determine the existence or degree of change, it is considered appropriate for such research (Cohen, Manion \& Morrison, 2000).

\section{Data Collection and Analysis}

In 2017-2018 academic year in Turkey, game coding competition was organized with the coordination of a government school and with the support by the government agencies in order to monitor students' coding skills. The data of this research were obtained from the games coded by the students who participated in the competition '2018 National Encoding My Game". The students were asked to design a game using 'Scratch 2.0' program on a topic that they determined without any field constraint. The competitors were middle school students and they were asked to form a group of up to 3 students in their own schools and to encode their games under the supervision of a teacher. They were asked to use Turkish characters and contents, and they were also asked not to produce violent-based games.

There were 456 applications from 281 institutions all around Turkey. 456 works were identified as the universe of this research. The sample consisted of 300 randomly selected works. The data of this research were obtained from the works included in this competition. The data analysis was conducted by the researchers. The works in the competition were examined through the use of "Scratch 2.0" program. Checklists were created by the researchers to analyze the data. In these checklists, mental structures (abstract, concrete, mixed and simple content), the use of violent content, the characters, the subject of the game, the type of points, the dominant colors were examined. Then, information technologies experts were consulted about the appropriateness of the data provided. The findings were gathered about the contents over which a consensus was reached after getting the feedback. 


\section{Participants}

In Table 1, it is seen that there are 281 applications from the participating schools. $60 \%$ of these schools $(\mathrm{f}=182)$ are middle schools, $8 \%(f=25)$ are imam hatip middle schools, $24 \%(f=74)$ are colleges and $13 \%(f=13)$ are science and art centers (BILSEM). As seen the participation in the competition is mostly from state schools, and at least in science and art centers.

Table 1. Distribution of works in the competition in terms of school type

\begin{tabular}{lll}
\hline School Type & $\mathrm{f}$ & $\%$ \\
\hline Middle School & 182 & 60 \\
Imam Hatip Middle School & 25 & 8 \\
College & 74 & 24 \\
Science and Arts Center & 13 & 4 \\
Total & 281 & 100 \\
\hline
\end{tabular}

Table 2 shows the gender distribution of participants and consultants. $25 \%(\mathrm{f}=235)$ of the participants were females and $75 \%(f=696)$ were males. $71 \%$ of the counselors $(f=212)$ were female and $29 \%(f=85)$ were male teachers.

Table 2. Gender distribution of participants and consultants

\begin{tabular}{llll}
\hline & Gender & f & $\%$ \\
\hline \multirow{3}{*}{ Student } & Girl & 235 & 25 \\
& Boy & 696 & 75 \\
& Total & 931 & 100 \\
& Female & 212 & 71 \\
& Male & 85 & 29 \\
& Total & 297 & 100 \\
\hline
\end{tabular}

Table 3 shows the number of provinces where the participant institutions are located. It was observed that the participants were mostly from Ankara with \%19 (f=54), Istanbul with 16\% ( $\mathrm{f}=47)$, Izmir with 4\% (f = 4), Manisa with $4 \%$, Bursa with \% $3(\mathrm{f}=3)$. It was also observed that the participations were generally from Turkey's three largest cities, and 57 of 81 provinces participated in the competition.

Table 3. Number of the provinces in which the applicant institutions are located

\begin{tabular}{|c|c|c|c|c|c|c|c|c|}
\hline City & $\mathrm{f}$ & $\%$ & City & $\mathrm{f}$ & $\%$ & City & $f$ & $\%$ \\
\hline Ankara & 54 & 19 & Muğla & 4 & 1 & Aksaray & 1 & 1 \\
\hline İstanbul & 47 & 16 & Adana & 3 & 1 & Bartın & 1 & 1 \\
\hline İzmir & 12 & 4 & Amasya & 3 & 1 & Burdur & 1 & 1 \\
\hline Manisa & 12 & 4 & Aydın & 3 & 1 & Çanakkale & 1 & 1 \\
\hline Bursa & 10 & 3 & Bolu & 3 & 1 & Çorum & 1 & 1 \\
\hline Kocaeli & 8 & 2 & Erzurum & 3 & 1 & Diyarbakır & 1 & 1 \\
\hline Antalya & 7 & 2 & Hatay & 3 & 1 & Gümüşhane & 1 & 1 \\
\hline Düzce & 6 & 2 & Mersin & 3 & 1 & Kahramanmaraş & 1 & 1 \\
\hline Rize & 6 & 2 & Trabzon & 3 & 1 & Karaman & 1 & 1 \\
\hline Tokat & 6 & 2 & Afyon & 2 & 1 & Kars & 1 & 1 \\
\hline Denizli & 5 & 1 & Bilecik & 2 & 1 & Kırıkkale & 1 & 1 \\
\hline Sakarya & 5 & 1 & Elâzı̆̆ & 2 & 1 & Kırklareli & 1 & 1 \\
\hline Samsun & 5 & 1 & Eskişehir & 2 & 1 & Mardin & 1 & 1 \\
\hline Tekirdağ & 5 & 1 & Isparta & 2 & 1 & Niğde & 1 & 1 \\
\hline Uşak & 5 & 1 & Kastamonu & 2 & 1 & Ordu & 1 & 1 \\
\hline Balıkesir & 4 & 1 & Konya & 2 & 1 & Şanlıurfa & 1 & 1 \\
\hline Batman & 4 & 1 & Kütahya & 2 & 1 & Yalova & 1 & 1 \\
\hline Gaziantep & 4 & 1 & Osmaniye & 2 & 1 & Yozgat & 1 & 1 \\
\hline Giresun & 4 & 1 & Sivas & 2 & 1 & & & \\
\hline Kayseri & 4 & 1 & Zonguldak & 2 & 1 & & & \\
\hline
\end{tabular}

\section{Findings}

In this section, the findings related to the sub-problems of this research are presented. 


\section{Game Contents Coded by Students}

Figure 1 shows the basic features of the games produced by the students. (a) A skier, track, snow and trees are seen in concrete items. It is observed that student used only the concrete elements in the game design. (b) In the visual of abstract elements, it is seen that only the imaginary characters are used in the game. (c) In a complex content game, it is seen that the contents are used randomly. Two elephants are trying to wet a mouse by throwing some water on it. There are four Turkish flags in the edges of the visual. (d) In the violent element, a Ninja character is expected to break some boxes and reach the star. As the ninja progresses, it is understood that the rays will smash and damage him.

(a) concrete items

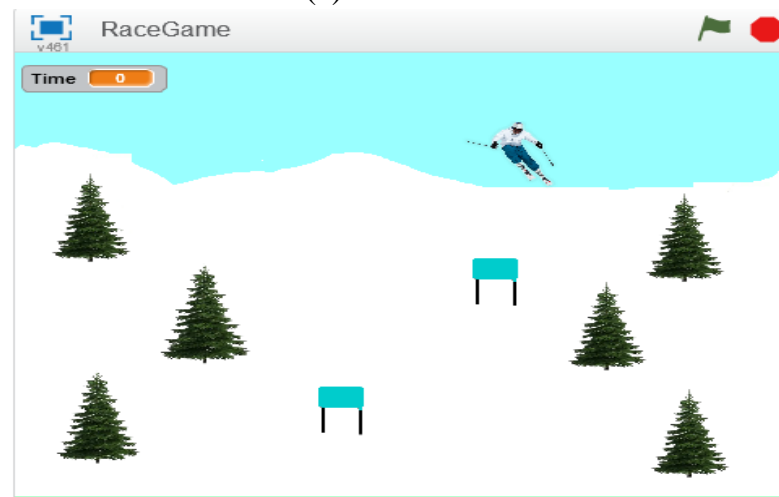

(c) complex content
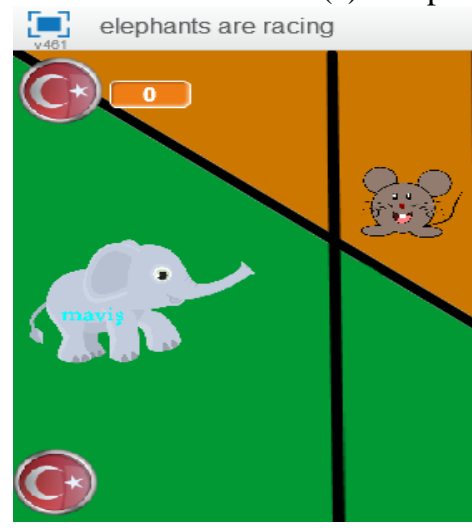

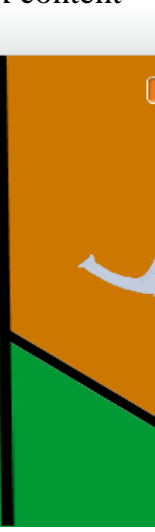

(b) abstract items

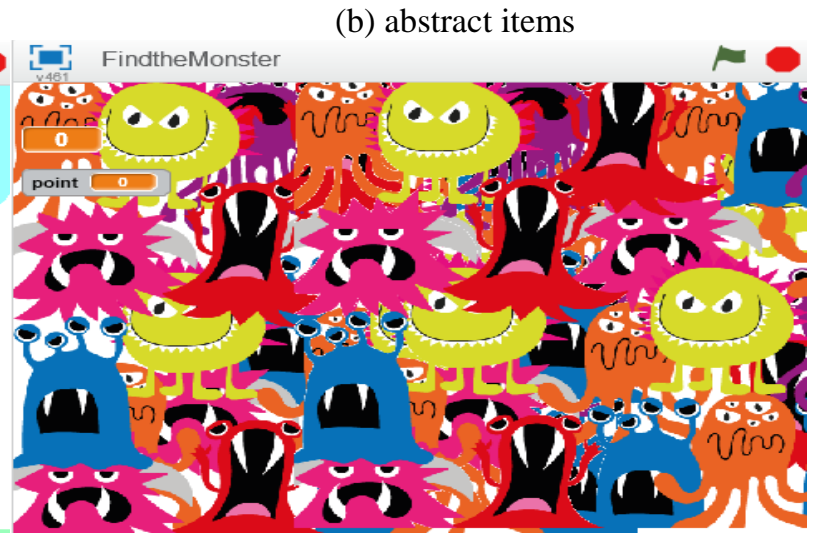

(d) violent elements

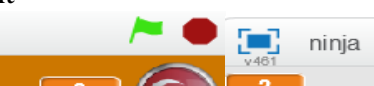

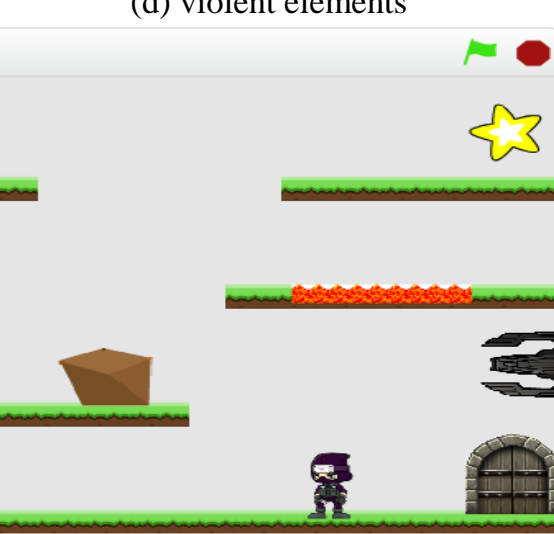

Figure 1. Visuals Contents

Table 4 shows the basic characteristics of the contents of the games that the students encoded. According to this table, students created a total of 300 games. They used concrete elements in $68 \%(\mathrm{f}=205)$ of the games and used abstract elements in $27 \%$ of the games ( $\mathrm{f}=83)$. Of the game contents encoded by the students, $49 \%(\mathrm{f}=148) \mathrm{had}$ a complex content and $47 \%(f=143)$ had a simple content. Violent elements were witnessed in $13 \%(f=50)$ of these contents.

Table 4. Basic features of the content of the games encoded by the students

\begin{tabular}{lll}
\hline Content & f & $\%$ \\
\hline Concrete & 205 & 68 \\
Abstract & 83 & 27 \\
Complex content & 148 & 49 \\
Simple content & 143 & 47 \\
Violent elements & 50 & 16 \\
\hline
\end{tabular}

\section{Game Types Coded by Students}

Figure 2 shows the followings: (a) a visual of an educational-instructional game in which the player is asked to find the words associated with "respect"; (b) a visual of a score collection game in which the rabbit is expected to collect fruits; (c) a male character to reach the orange area through the maze and collect the gold in this process; 
(d) quiz show in which a girl character on the screen asks some questions and the player is expected to answer those questions by writing them in the given space.

(a) Educational - Tutorial

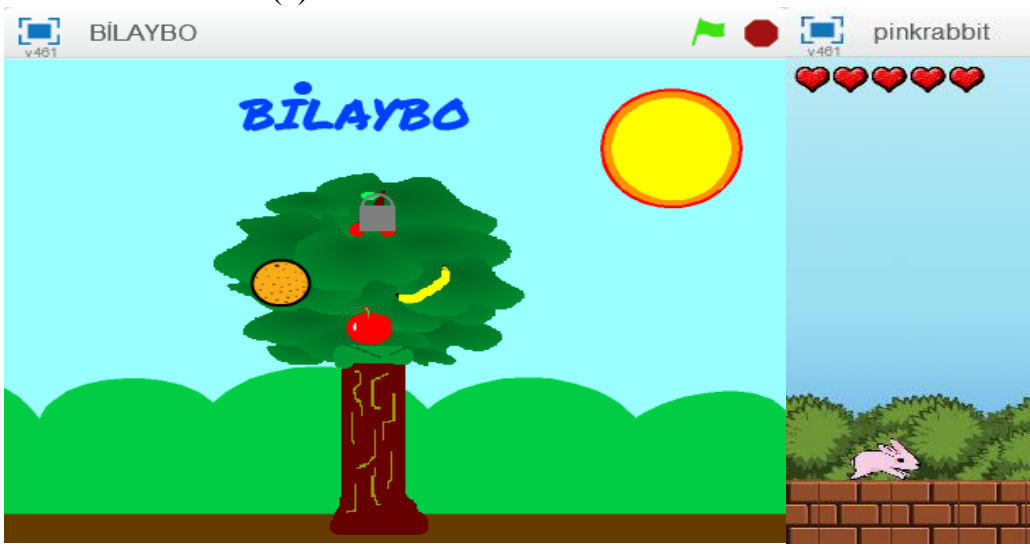

(c) Maze (b) Score collection

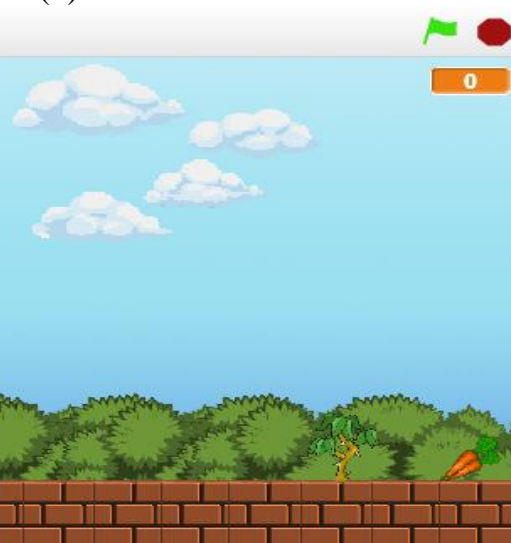

(d) Quiz show

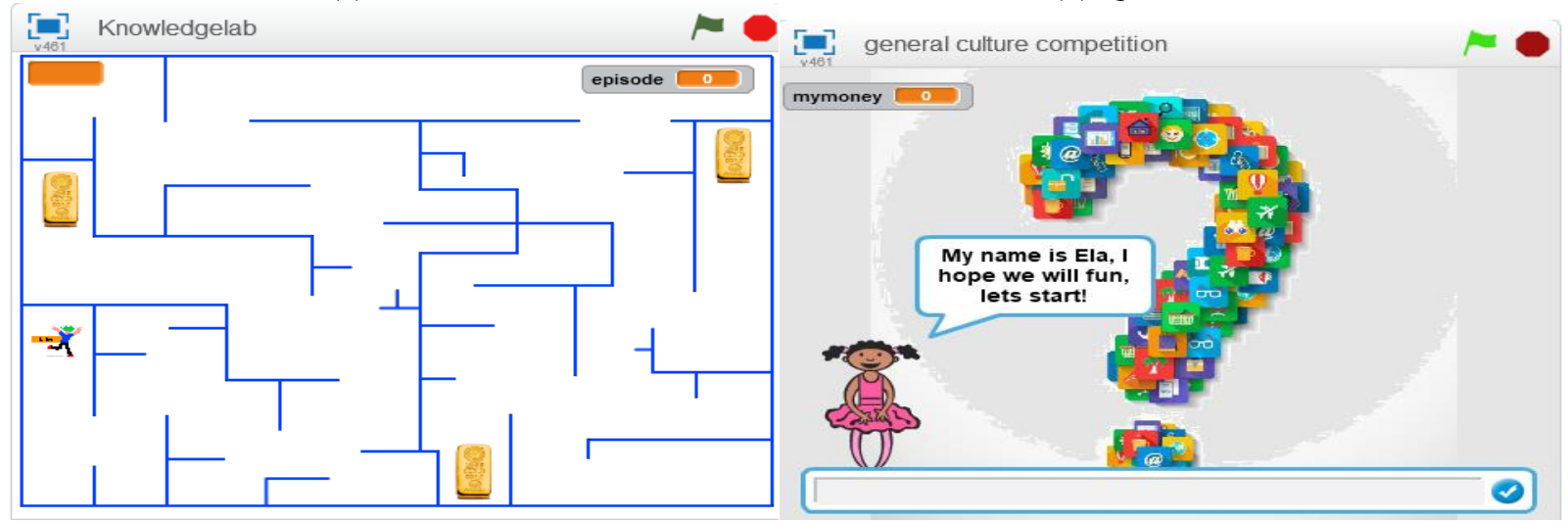

Figure 2. The visuals of Game Types

Table 5 shows the types of the games that students encoded. According to this table, of the 300 games encoded by students, $33 \%$ are score collection $(\mathrm{f}=100), 24 \%$ educational tutorial $(\mathrm{f}=74), 14 \%$ quiz show $(\mathrm{f}=44), 6 \%$ hurdle race $(\mathrm{f}=20), 6 \%$ maze $(\mathrm{f}=18), 4 \%$ concentration $(\mathrm{f}=14), 5 \%$ garbage pickup - recycling $(\mathrm{f}=16), 2 \%$ race $(\mathrm{f}=6), 1 \%$ advancement $(\mathrm{f}=4), 0.5 \%$ guessing $(\mathrm{f}=2), 0.5 \%$ following up $(\mathrm{f}=2)$

Table 5. The types in the games that the students encoded

\begin{tabular}{lll}
\hline Subject & f & $\%$ \\
\hline Score collection & 100 & 33 \\
Educational tutorial & 74 & 24 \\
Quiz show & 44 & 14 \\
Hurdle race & 20 & 6 \\
Maze & 18 & 6 \\
Garbage Pickup & 16 & 5 \\
Concentration & 14 & 4 \\
Race & 6 & 2 \\
Advancement & 4 & 1 \\
Guessing & 2 & 0.5 \\
Following up & 2 & 0.5 \\
Total & 300 & 100 \\
\hline
\end{tabular}

\section{Characters Used in Coded Games}

Figure 3 shows the characters that students created in the games. (a) In the category of human man, with the use of the arrow keys, a male character is expected to dance. (b) In animal category, a cat character is expected to pass 
obstacles. (c) A ball image in the object category is expected to pass obstacles with the use of the arrow keys. (d) In the category of fantasy character, a ghost image asks a boy various question.

(a) human-man character

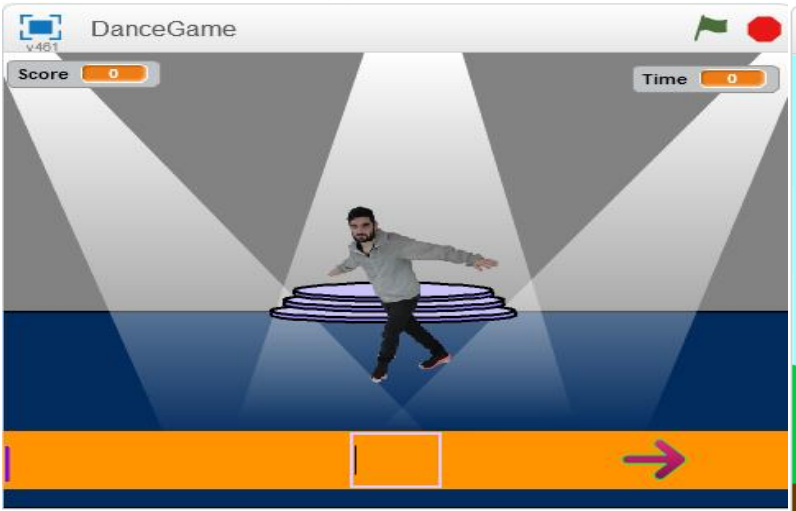

(c) object-ball (b) animal-cat

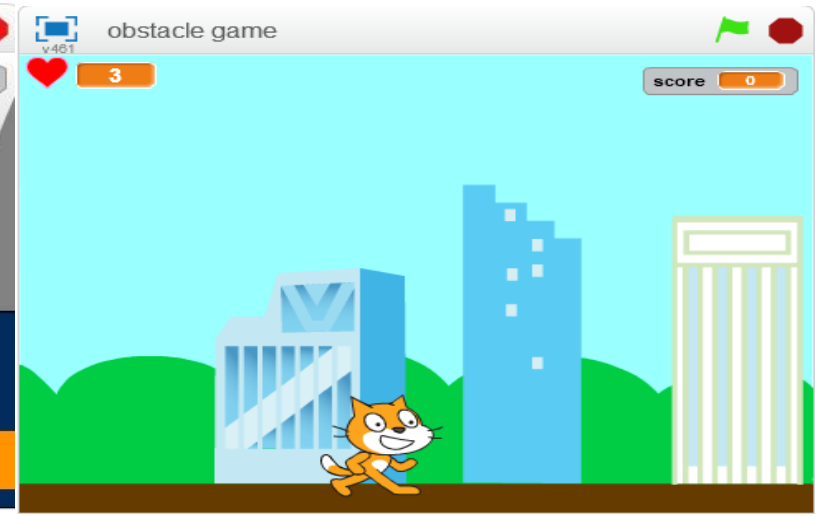

(d) fantasy character-ghost

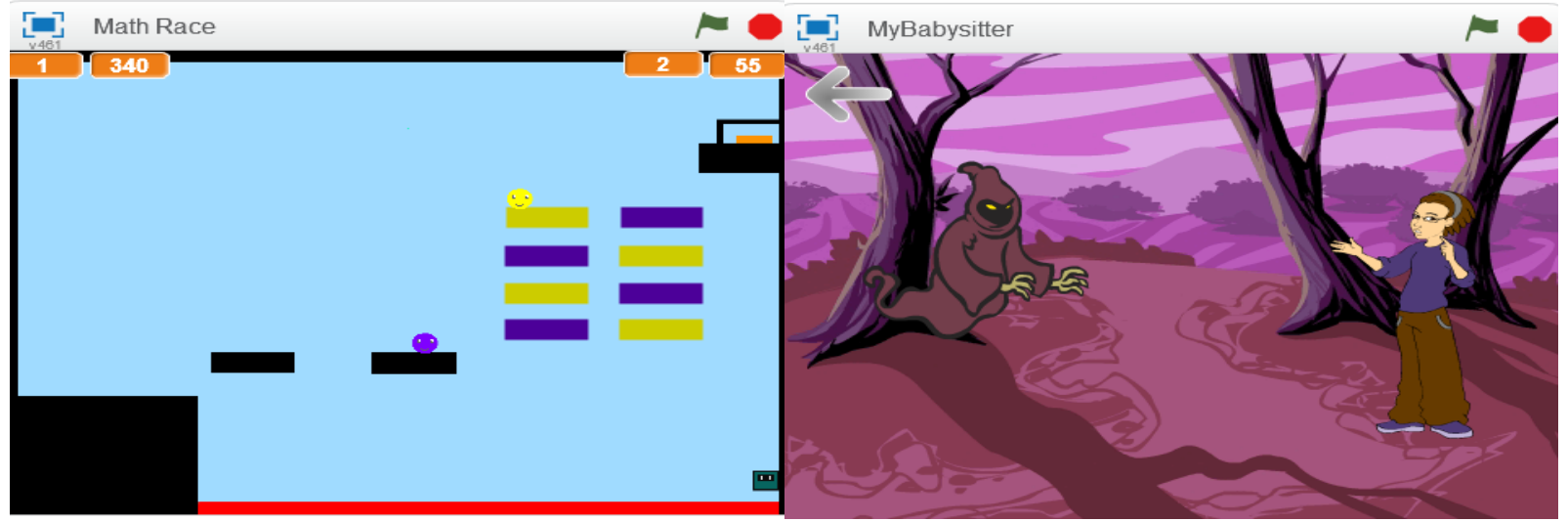

Figure 3. Visuals of the characters that students used in the games they encoded

Table 6 shows the characters students used in the games that they produced. It is seen that a total of 300 games were produced and students created 341 characters in total. However, in this table, only the characters with the frequency number of more than 1 have been issued.

Table 6. The contents of the characters that the students used in the games they encoded

\begin{tabular}{llllllllllll}
\hline Human & $\mathrm{f}$ & $\%$ & Animal & $\mathrm{f}$ & $\%$ & Object & $\mathrm{f}$ & $\%$ & Fantasy & $\mathrm{f}$ & $\%$ \\
\hline $\begin{array}{l}\text { Female } \\
\text { Character }\end{array}$ & 18 & 26 & Bat & 23 & 36 & Ball & 19 & 27 & $\begin{array}{l}\text { Cartoon } \\
\text { character }\end{array}$ & 39 \\
Male & 17 & 24 & Cat & 10 & 15 & Space craft & 14 & 20 & Puppet & 16 & 37 \\
Character & & & & & & & & & & & \\
Child & & & & & & & & & & & \\
Astronaut & 9 & 13 & Fish & 6 & 9 & Number & 8 & 11 & Witch & 5 & 11 \\
Farmer & 9 & 13 & Mouse & 5 & 7 & Picture & 7 & 10 & Monster & 3 & 6 \\
Man & 4 & 5 & Bug & 4 & 6 & Balloon & 6 & 8 & Ghost & 2 & 4 \\
Footballer & 4 & 5 & Bird & 3 & 4 & Fire & 2 & 2 & & \\
Diver & 3 & 4 & Cancer & 2 & 3 & Flame & 2 & 2 & & \\
Apple & 2 & 2 & Horse & 2 & 3 & Bomb & 2 & 2 & & \\
Human & 2 & 2 & Dog & 2 & 3 & Wheel & 2 & 2 & & \\
Shark & 2 & 3 & Jet & 2 & 2 & Jet & 2 & 2 & & \\
Worm & 2 & 3 & Robot & 2 & 2 & Robot & 2 & 2 & & \\
Rabbit & 2 & 3 & Rifle & 2 & 2 & Rifle & 2 & 2 & & \\
Dice & 2 & 2 & & & & Jet & 2 & 2 & & \\
Total & 69 & 100 & Total & 63 & 100 & Total & 70 & 100 & Total & 43 \\
\hline
\end{tabular}


Therefore, the table shows only 245 characters in total. In terms of their characteristic features, these characters are divided into four groups as human, animal, object and fantasy characters. Out of 245 characters, $28 \%$ ( $\mathrm{f}=69$ ) are human figures, $25 \%(\mathrm{f}=63)$ animals, $28 \%(\mathrm{f}=70)$ objects and $17 \%(\mathrm{f}=43)$ fantasy characters. It is seen that as a human character, participant students produced $26 \%(\mathrm{f}=18)$ female characters, $24 \%(\mathrm{f}=17)$ male characters, 13 $\%(\mathrm{f}=9)$ astronauts and $13 \%(\mathrm{f}=9)$ farmers. Out Of the 245 characters, 63 are animal characters. It is seen that most preferred $36 \%(\mathrm{f}=23)$ are bats, $15 \%(\mathrm{f}=10)$ cats and $9 \%(\mathrm{f}=5)$ fish. Out of the 245 characters that were produced by the participant students, 70 of them are objects. It is seen that $27 \%$ of these object characters are $(\mathrm{f}=19)$ balls, $20 \%(\mathrm{f}=14)$ spacecraft, $11 \%(\mathrm{f}=8)$ numbers. Out of the 245 games produced by the students, 43 of them consist of fantasy, that is, abstract characters. Of these characters, $39 \%(\mathrm{f}=17)$ are cartoon characters (abstract characters), $37 \%(\mathrm{f}=16)$ puppets and $11 \%(\mathrm{f}=5)$ witches.

\section{Objects Used in Coded Games}

In Figure 4, there are the visuals of (a) human and animals, (b) environmental factors, (c) space, (d) object categories. (a) In the visual of humans and animals' category, a there is a character that cleans the environment. b) In the category of environmental factors, there is a girl character who is sensitive to environmental pollution. There are clouds and apples at the background of the visual. (c) In the category of space, there are stars, the Sun and the Earth at the background. (d) In object-numbers category, the numbers should be placed in a square which is divided into 9 parts.

(a) human and animal female character (b) environmental elements cloud and apple

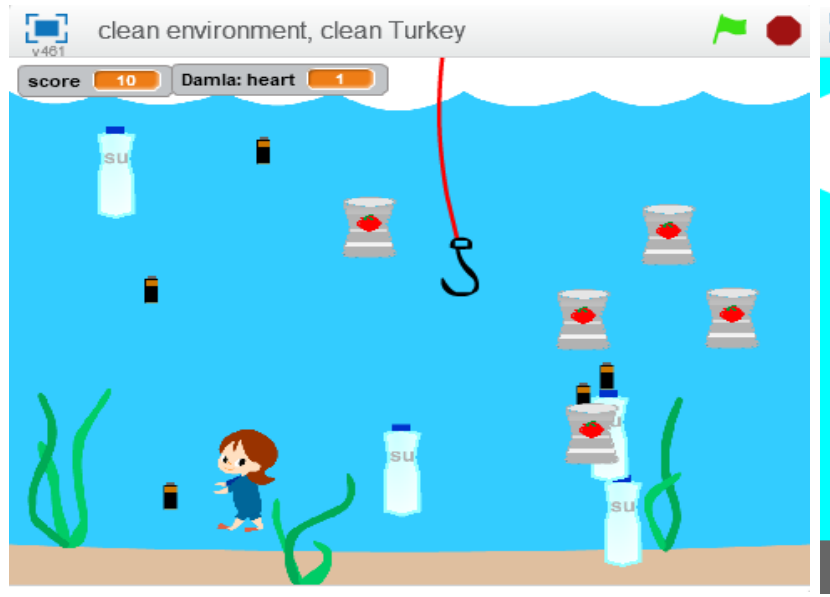

(c ) space-star

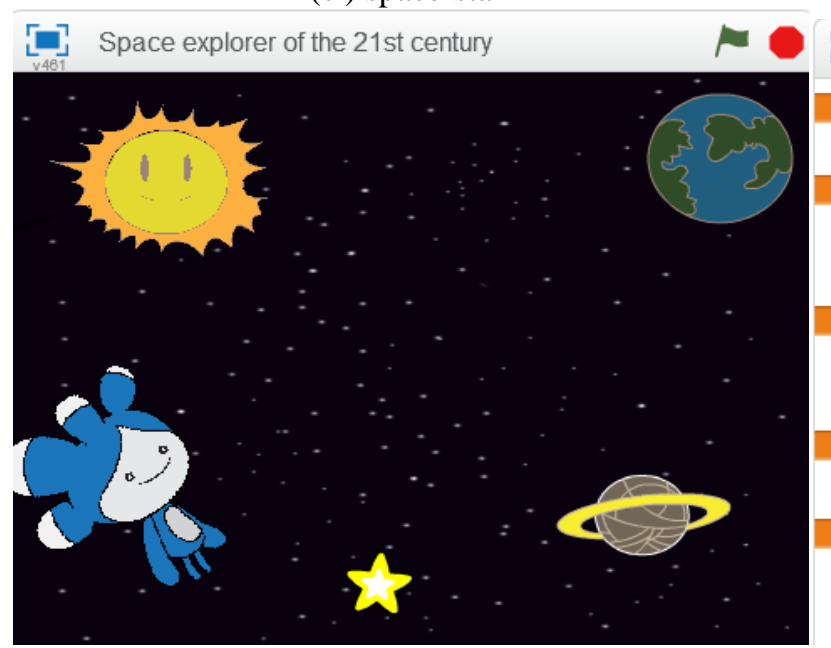

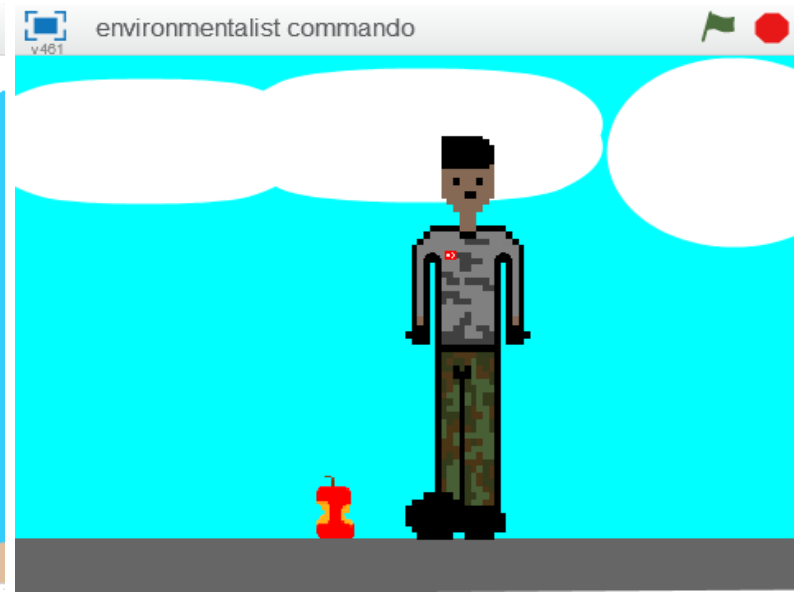

(d) object-numbers

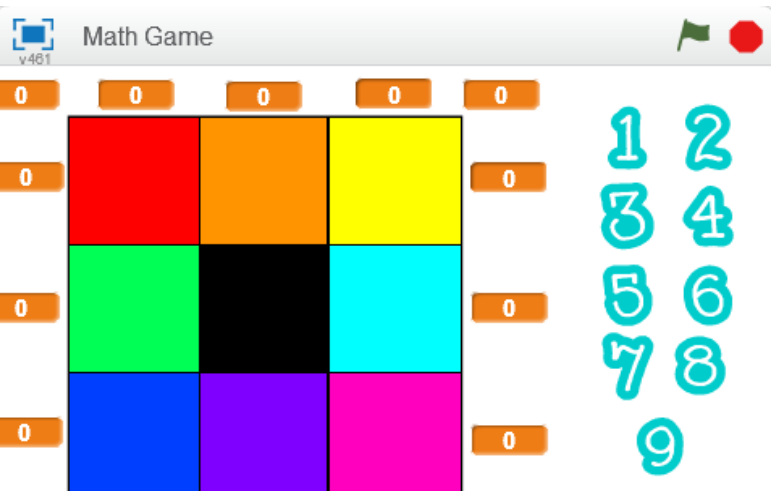

Figure 4. Visuals of objects used in coded games 
Table 7 lists the objects that students used on their interfaces in the games they encoded. There were 1295 objects in the games that the students encoded. These codes are divided into six categories as humans and animals $(f=312)$, environmental factors $(f=304)$, space $(f=110)$, technological objects $(f=140)$, imaginary characters $(f=74)$ and objects $(\mathrm{f}=352)$.

Table 7. Objects used coded games

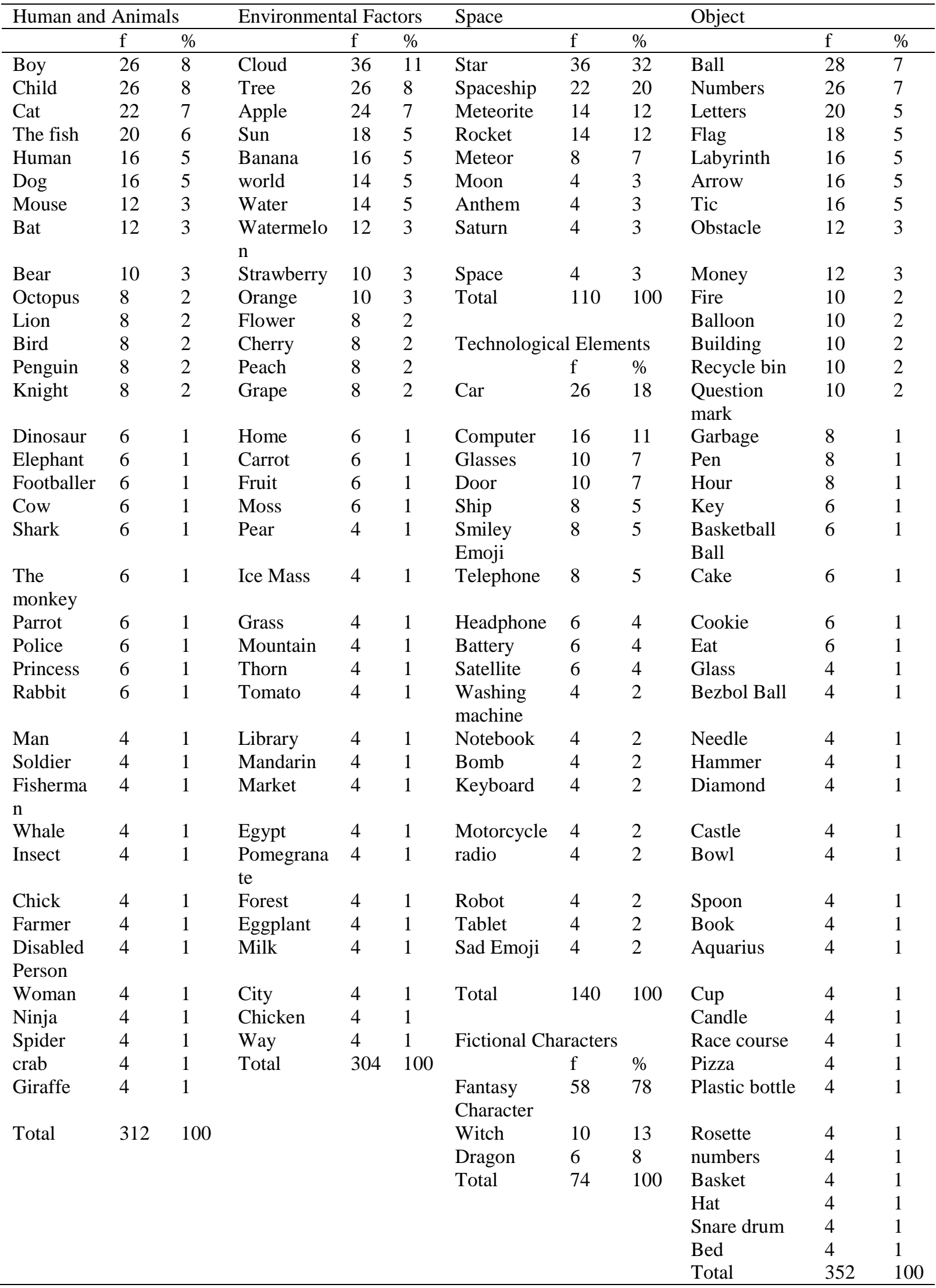


In the games that the students encoded, in human and animal category, $8 \%$ were male children $(\mathrm{f}=26), 8 \%$ were female children $(\mathrm{f}=26)$ and $7 \%$ were cats $(\mathrm{f}=22)$. As for environmental factors, $11 \%$ were clouds $(\mathrm{f}=36), 8 \%$ trees $(f=26), 7 \%$ apples $(f=24)$. As for the space category, $22 \%$ were stars $(f=36) ; 22 \%$ were spacecraft $(f=$ $20)$, and $14 \%$ were meteorites $(f=12)$ and rockets $(f=12)$. In the technological item's category, $18 \%$ were cars $(\mathrm{f}=26), 11 \%$ computers $(\mathrm{f}=16)$ and $7 \%$ glasses $(\mathrm{f}=10)$. As for the imaginary characters, $78 \%$ were fantasy characters $(f=58), 13 \%$ witches $(f=13)$ and $8 \%$ dragons $(f=6)$. In the object's category, $7 \%(f=28)$ were balls, $7 \%(f=26)$ numbers, $5 \%(f=20)$ letters.

\section{Awards Used Coded Games}

Figure 5 illustrates the visuals of the awards which the students used in the games they encoded. (a) In the Score category, the character is expected to choose the right foods for a healthy life. In return, the character earns points. In Not-used category, when the player clicks on the images, the English words for the fruits are heard. However, there are no scores assigned. (c) In the category of Life, the male character is expected to proceed without touching any garbage. If the character touches any garbage, its life (hearts) decreases. (d) In the Time category, a witch character is expected to travel in the city in a given period of time.

(a) score

(c) life

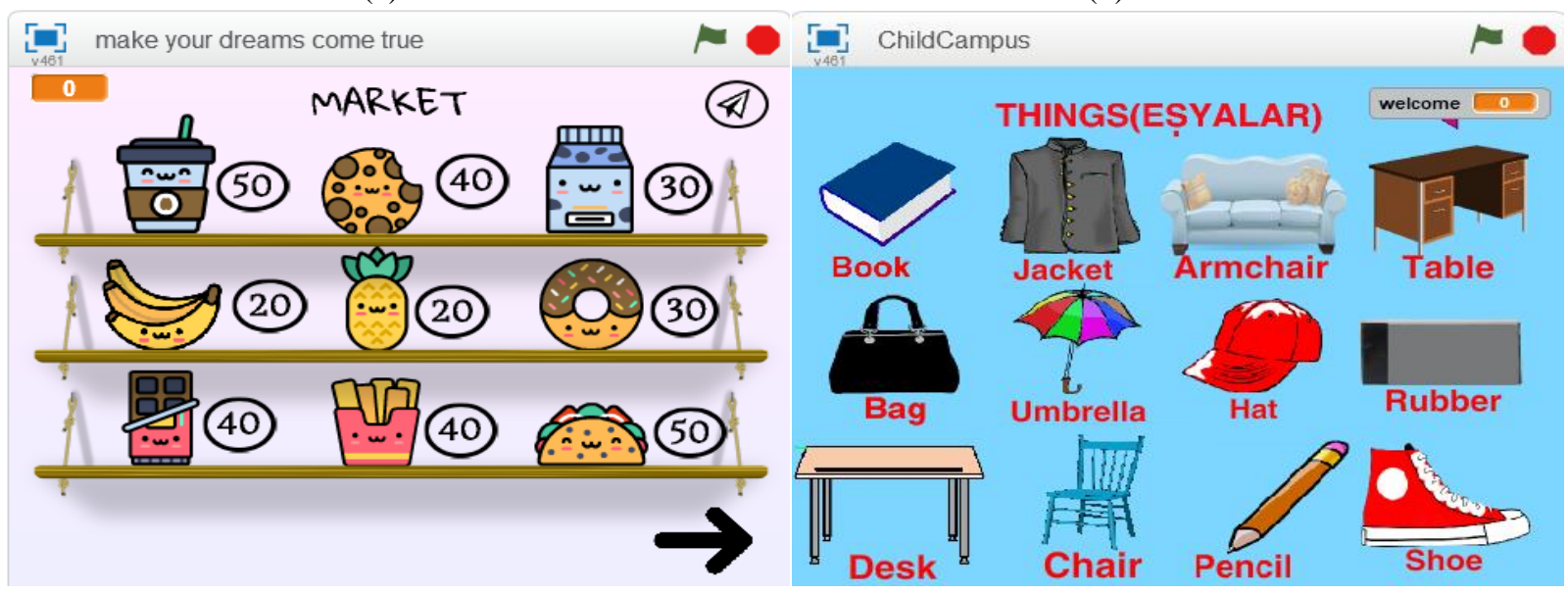

(b) not used

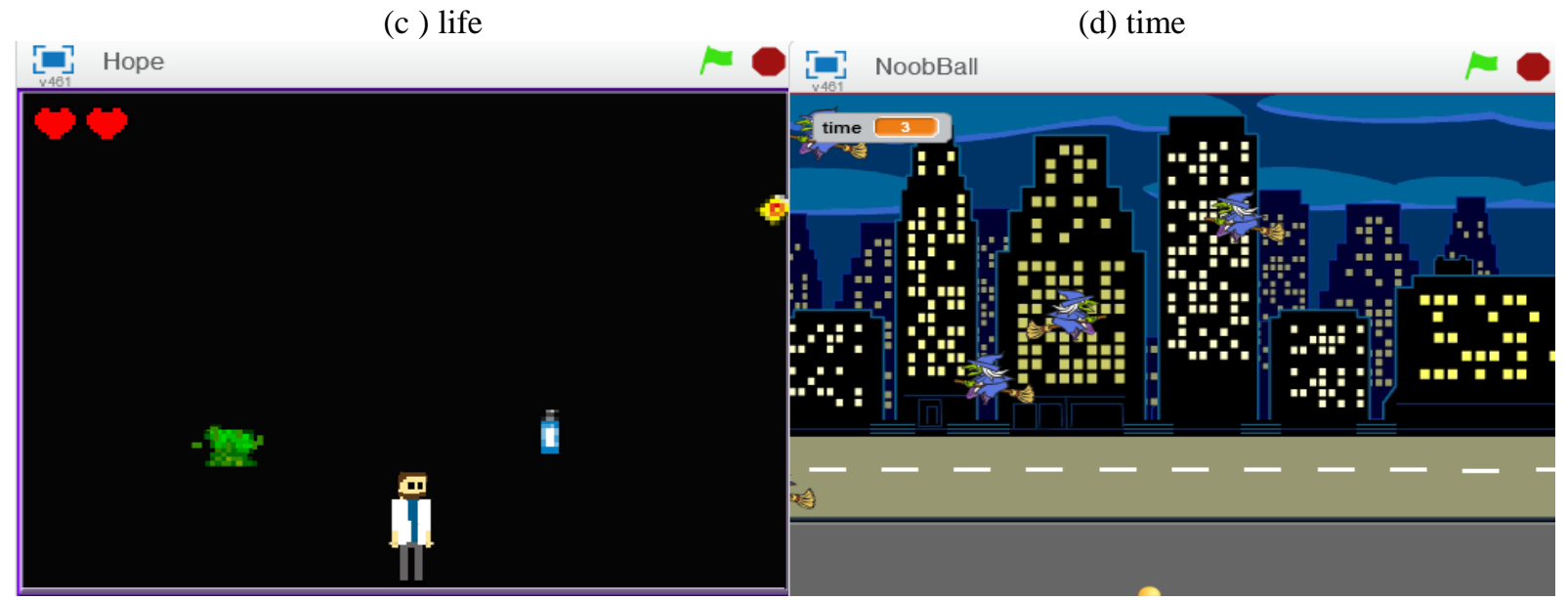

Figure 5. Images of the awards used by the students in the games they encoded

Table 8 shows the contents of the award used by the students in the games they encoded. It is seen that students mostly used $43 \%(f=130)$ points in the games they encoded. Beside this, there is not any award-winning criteria in the $19 \%(f=58)$ of the games. It is seen that $13 \%(f=41)$ of the awards were Life (hearts) and $4 \%(f=13)$ were Scores. Other elements that the students used were listed as $2 \%(\mathrm{f}=7)$ for foods, $\% 2$ ( $\mathrm{f}=6)$ for the number of correct answers, $2 \%(\mathrm{f}=6)$ for money, $1 \%(\mathrm{f}=3)$ for levels, $1 \%(\mathrm{f}=3)$ for hits, $1 \%(\mathrm{f}=3)$ for animals, $1 \%(\mathrm{f}=3)$ for the number of goals, $1 \%(\mathrm{f}=3)$ for keys. 
Table 8 . The contents of the awards used by the students in the games they encoded

\begin{tabular}{llllll}
\hline Award & $\mathrm{f}$ & $\%$ & Award & $\mathrm{f}$ & $\%$ \\
\hline Point & 130 & 43 & Gold & 3 & 1 \\
Not used & 58 & 19 & Ammunition & 2 & 1 \\
Life (heart) & 41 & 13 & Member & 1 & 1 \\
Score & 13 & 4 & Tooth & 1 & 1 \\
Time & 12 & 4 & Winner & 1 & 1 \\
Food & 7 & 2 & Number of saved files & 1 & 1 \\
Number of correct answers & 6 & 2 & Completed game & 1 & 1 \\
Money & 6 & 2 & Badge & 1 & 1 \\
Level & 3 & 1 & Number & 1 & 1 \\
Hit & 3 & 1 & Wrong attempts & 1 & 1 \\
Animal & 3 & 1 & Star & 1 & 1 \\
Number of goals & 3 & 1 & Game completion & 1 & 1 \\
Key & 3 & 1 & Total & 300 & 100 \\
\hline
\end{tabular}

\section{Colors Used Coded Games}

Figure 6 shows the colors used intensively by students in the games they encoded. (a) in the Blue visual, a fisherman is fishing in a lake. (b) In the Green visual, it appears that a racer is moving on a road without hitting any obstacles. It is seen that the green color is used intensively in this visual. (c) In the No Dominant Color visual, water drops is expected to be collected through a bucket. However, there is no dominant color used in this visual. (d) In the Red visual, one or two players are expected to meet the ball. The Red color is used intensively in the background.

(a) blue

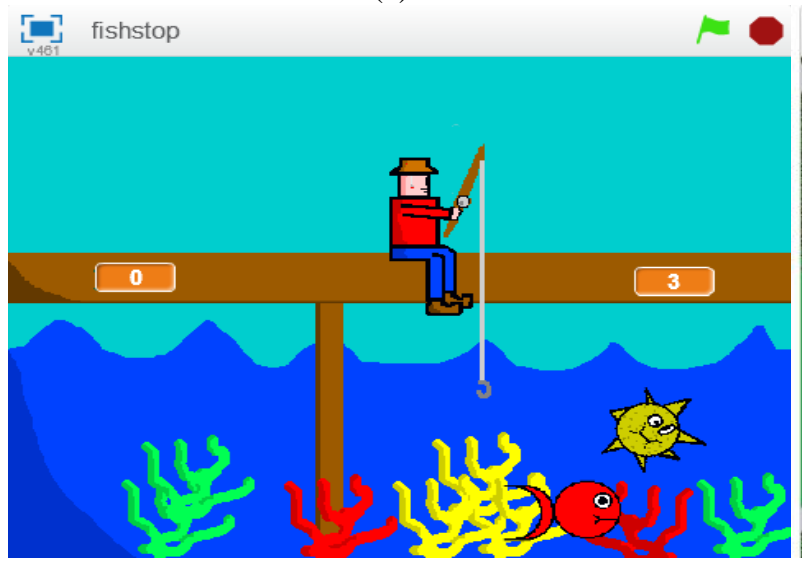

(c ) no dominant color (b) green

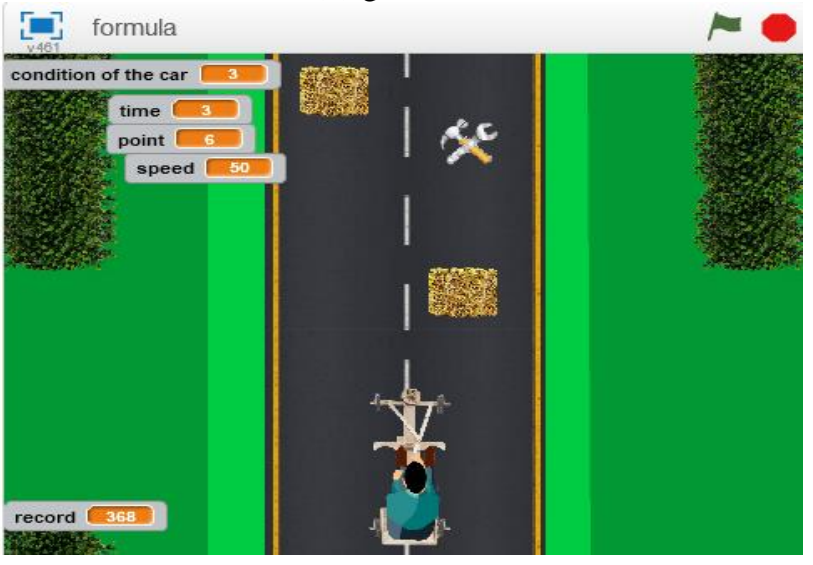

(d) red

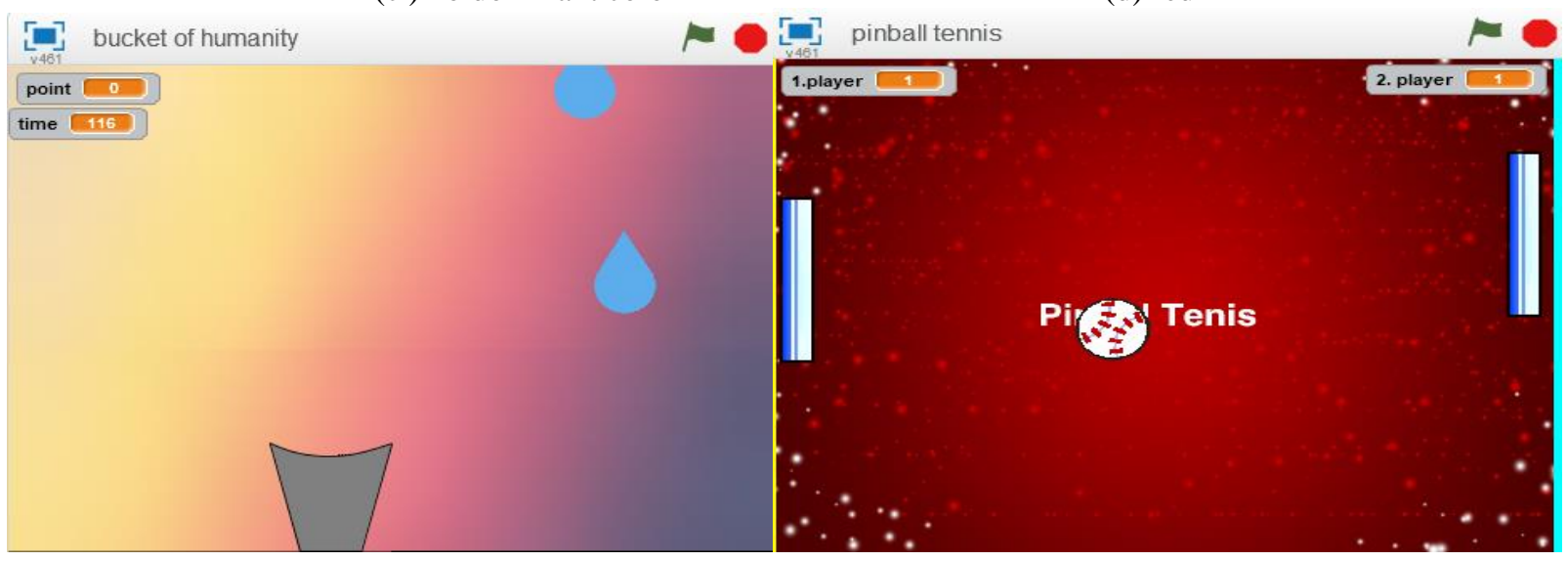

Figure 6 . Intensive colors used by students in the games they encoded 
Table 9 shows the contents of the colors that the students used in the games they encoded. It is seen that the students mostly used the color blue in their games, which is $21 \%(\mathrm{f}=65)$. Following this, there comes the color green, which is $16 \%(\mathrm{f}=48)$. Then, $12 \%(\mathrm{f}=36)$ appears to be not a dominant color. The other rates are as follows; $9 \%(\mathrm{f}=28)$ for red, $8 \%(\mathrm{f}=25)$ for white, $8 \%(\mathrm{f}=25)$ for black, $6 \%(\mathrm{f}=20)$ for magenta, $4 \%(\mathrm{f}=14)$ for grey, $3 \%(\mathrm{f}=9)$ for brown, $3 \%(\mathrm{f}=9)$ for pink, $2 \%(\mathrm{f}=6)$ for purple, $2 \%(\mathrm{f}=6)$ for yellow, $1 \%(\mathrm{f}=5)$ for orange, 1 $\%(\mathrm{f}=3)$ for real pictures and $1 \%(\mathrm{f}=1)$ for lilac.

Table 9. Content related to the colors that students used intensively in the games they encoded

\begin{tabular}{lll}
\hline Color & $\mathrm{f}$ & $\%$ \\
\hline Blue & 65 & 21 \\
Green & 48 & 16 \\
No dominant color & 36 & 12 \\
Red & 28 & 9 \\
White & 25 & 8 \\
Black & 25 & 8 \\
Magenta & 20 & 6 \\
Grey & 14 & 4 \\
Brown & 9 & 3 \\
Pink & 9 & 3 \\
Purple & 6 & 2 \\
Yellow & 6 & 2 \\
Orange & 5 & 1 \\
Real picture & 3 & 1 \\
Lilac & 1 & 1 \\
Total & 300 & 100 \\
\hline
\end{tabular}

\section{Discussion and Conclusion}

With the rapid advancement of the technology, the traditional game concept has changed, and digital items have become an indispensable part of our daily lives thanks to the "digital games" concept. This study examines the variables which were used by the middle school students in creating digital games in the scope of technologyoriented STEM education. As Prensky (2001) stated before, what creates a game is the rules, goals and objectives, feedback, struggle / race / challenge / contrast, interaction, presentation and a story. Today, as a result of the rapid advancement in the technology, the Scratch-based game technologies increase the importance of technologies used in educational environments. Findings have shown that men were more interested in the game production process than females, and it is seen that counselors were all females. These findings support Becta's (2001) conclusion that teachers should also be included in the process of an educational game production. It has been observed that the participants in the competition were mostly from Turkey's first three largest cities. It has also been observed that of the 81 provinces, 57 of them took part in the competition. With all these findings, it could be said that computers created equal opportunities for coding and production process. It can be seen clearly that the students' coding skills can be developed through such competitions.

As stated by Shin, Park and Bae (2014), Karabak and Güneş (2013), Monroy-Hernández and Resnick (2008), the students learn to produce digital games using their creativity, design some characters for the game, write stories, make feedbacks and use reward mechanisms, which are all essential for the improvement of their digital understanding. Therefore, they can gain some $21^{\text {st }}$ century skills of systematical thinking such as computational thinking or lead them to STEM career paths In this study, it has been observed that students used concrete elements, abstract elements, complex content, simple and violent elements in digital games. According to Yengin (2010), digital games overlap with the expressions of abstract games, meaningful games, meaningless games and phased games. It has also been observed that while producing digital games, some of the students consciously or unconsciously used the violent contents such as weapons, bullets, rays and swords that will physically damage the character. It is stated that violent digital games cause aggressive behaviors, thoughts and physiological stimulation to increase, and also, they bring about desensitization against violence and low empathy for the long-time players and decrease the prevalence of benevolent behavior (Anderson, Shibuya \& Ihori 2010). In the researches to be made in the future, the factors which make the students use the content of violence could be dealt with. Psychological effects of the digital games could be investigated.

In this study, the included game types were educational-tutorial, quiz, obstacle passing, maze, attention, garbage collection - recycling, race, progress, prediction, and follow-up. These results are to some extent similar to the 
classification by Mitchell and Smith (2004). In some of the games, it has been observed that students combined the course contents with digital games by using educational technologies or use of assessment STEM learning outputs. Educational-instructional games allow the students to learn the new concepts. Quiz shows integrate the knowledge with the technology. These results, as stated by Çatlak, Tekdal and Baz (2015), help integrate the technology with other courses besides programming.

The results show that the main characters the students used in the games they encoded were human figures, animals, objects and fantasy characters. However, Kan (2010) states that male and female roles are represented differently in computer games, considering the representation of the human figure in this study, it is seen the proportions of male and female representations were equal. Our ultimate goal should be to make games for learning more accessible and rich gaming experiences for all. Many of the changes in teaching and learning that came out of the gender equity movement improved the situation for all students, and not just for girls and women (Kafai, 2008). Exposing underrepresented students (e.g., females, minorities, and rural students) to preengineering skills through robotics and game design has the potential to increase their interest and to provide them with the skills needed to create a diverse workforce (National Research Council (NRC) 2011). Preparing students to succeed in STEM is crucial to ensuring that students have access to these and other STEM occupations in the future. (Leonard et al.,2016). In the interfaces that students produced, there were people and animals, environmental factors, space, technological elements, imaginary characters and various objects included. The results show that the students used the characters and infrastructures that the program already offered to them. Achievement systems or similar reward systems are becoming more and more popular in the games and they require for the addition of some scoreable targets to the game, apart from the inner mechanisms of the play such as meanings or purposes (Demirbaş, 2015). It has been observed that the students created some kind of reward systems for the games that they produced. They used the points most in their games. This result supports Prensky's expression that these systems provide feedback and shows the dimension of the interaction between the players or the computers.

It has been proved via the experiments that colors make some psychological effects and the saturation of the colors gives information about the species, values, temperatures, coldness, activity, passivity, lightness, stimulation, relaxation, joy and sadness (Özdemir, 2005). It has been observed that students mostly used blue, green and red colors in the games that they produced. Blue represents coolness, calmness, loyalty, confidence and relaxation and it has a soothing effect (Madden, Hewett \& Roth, 2000). Green represents freshness, coolness, growth, rebirth, peace, confidence, spring and vitality (Uçar, 2003, p.55). It appears that the students brought the calmness into the front in the games that they encoded.

Considering the concept of digital play, it has been observed that directing students to the game production process through competitions makes a great contribution to their 21 st century skills in STEM education. From this point of view, encouraging students and their counselors in the game production process will provide an added value to our country within the scope of the growing game market. Within the framework of this research, the participation of males should be well-balanced with that of females. Students should be encouraged to use original characters or themes and to produce original contents. In educational technologies, digital games encourage students to game production. It is important to provide students with the necessary educational contents for the game encoding.

Leonardo et al (2016) found that game design and gaming developed children's self-efficacy in technology, STEM attitudes/STEM careers, and computational thinking. In future studies, students' ability to produce games can be explored in depth, and the images used by students in producing games can be investigated through qualitative research in STEM education. The success of the games with high sales can be examined. With the use of these games, students' influence on STEM interest and STEM motivation can be investigated. Scratch 2 and the use of other educational tools in educational technologies, factors related to students' success can be examined in STEM education. Game design have not only been extolled for their role in learning but have also been identified as pathways to broaden participation in STEM and STEM-related careers (Caron 2010; Sheridan et al. 2013). This research is limited only to the game connected to this contest. The research can be repeated with field-specific content at primary, middle, high school and higher education levels.

\section{References}

Anderson, C. A., Shibuya, A., Ihori, N., (2010). Violent video game effects on aggression, empathy, and prosocial behavior in eastern and western countries: A meta-analytic review. Psychol Bull, 136(1), 151-173. 
British Educational Communications and Technology Agency (Becta) (2001) Primary Schools of the Future achieving today. Coventry: Becta.

Bostan, B. \& Tingöy Ö., (2015). Digital games: Design requirements and player psychology. Academic Journal of Information Technology. 6(19), 7-21.

Çankaya, S. \& Karamete A. (2008). The effects of educational computer games on students' attitudes towards mathematics course and educational computer games. Mersin University Journal of the Faculty of Education, 4(2), 115-127.

Caron D (2010) Competitive robotics brings out the best in students. Tech Dir, 69(6), 21-23.

Çatlak, Ş., Tekdal, M., Baz F.Ç. (2015) The status of teaching programming with scratch: a document review work, Journal of Instructional Technologies \& Teacher Education, (4)3,13-25.

Cohen, L., Manion, L. \& Morrison, K. (2000). Research methods in education. 5th ed. London New York: Routledge Falmer.

Coşkun, H. (2012). The effect of science teaching and educational games with scientific stories on students' academic achievement. Master Thesis, Erciyes University, Institute of Educational Sciences, Kayseri.

Demirbaş, K.Y. (2015) Problems of genre-based approaches to digital games: The case of platform games genre, Selçuk İletişim,9(1), 362-387.

Horzum, M. B. (2011). Examining computer game addiction level of primary school students in terms of different variables. Education and Science, 36(159), 56-68.

İşman, A. (2005). Öğretim teknolojileri ve materyal geliştirme [Instructional technologies and material development]. Ankara: PegemA Press.

Kan, D. (2010). Yeni medya aracı bilgisayar oyunlarında toplumsal cinsiyetin inşası [Gender building in new media tool computer games]. The Turkish Online Journal of Design, Art and Communication, (4)2, 5260.

Karabak, D. \& Güneş, A. (2013). Curriculum proposal for first class secondary school students in the field of software development, Journal of Research in Education and Teaching, 2(3), 175-181.

Kafai, Yasmin. (2008). Considering gender in digital games: Implications for serious game designs in the learning sciences. Computer-Supported Collaborative Learning Conference, CSCL. 422-429.

Karasar N (2003). Scientific research method-concepts principles techniques (7th Ed.). Ankara: Nobel

Kim, C., Kim, M. K., Lee, C., Spector, J. M., \& DeMeester, K. (2013). Teacher beliefs and technology integration. Teaching and Teacher Education, 29(1), 76-85. http://doi.org/10.1016/j.tate.2012.08.005

Lemke, J. L. (2013). Investigating interactive immersive worlds: Assessing the relevance of computer games for STEM learning environment design. Retrieved from https://bit.ly/2QcgRyj.

Leonard, J., Buss, A., Gamboa, R., Mitchell, M., Fashola, O. S., Hubert, T., Almughyirah, S. M. (2016). Using robotics and game design to enhance children's STEM attitudes and computational thinking skills. Journal of Science Education and Technology, 28(6), 860-876. doi:10.1007/s10956-016-9628-2

Lunce, L. M. (2006). Simulations, bringing the benefits of situated learning to the traditional classroom. Journal of Applied Educational Technology, 3(1), 37-45.

Madden, T.J., Hewett, K., \& Roth, M. S. (2000). Managing images in different cultures: a cross-national study of color meanings and preferences. Journal of International Marketing, (8)4, 90-107.

Malan, D. J., \& Leitner, H. H. (2007, March). Scratch for budding computer scientists. Paper presented at ACM Special Interest Group on Computer Science Education annual conference, Covington, KY.

Marcelino, M. J., Pessoa, T., Vieira, C., Salvador, T., \& Mendes, A. J. (2017). Learning computational thinking and scratch at distance. Computers in Human Behavior, 80, 470-477.

Mitchell, A. Smith, C.S. (2004). The use of computer and video games for learning. Learning and Skills Development Agency.

Monroy-Hernández, A. \& Resnick, M. (2008) Empowering kids to create and share programmable media, Interactions, 15, 50-53.

National Research Council (2011) Successful K-12 STEM education: identifying effective approaches in science technology, engineering and mathematics. National Academy Press, Washington.

Özdemir, T., (2005). Criteria that affect color selection in design. Çukurova University Journal of the Institute of Social Sciences, (14)2, 391-402.

Peppler, K. A., \& Kafai, Y. B. (2007). From SuperGoo to Scratch: Exploring creative digital media production in informal learning. Learning, Media and Technology, 32, 149-166.

Prensky, M. (2001). Digital Game-Based Learning. New York: McGraw-Hill.

Resnick, L. B. (2009). Nested learning systems for the thinking curriculum. Educational Researcher, 39, 183-197. http://dx.doi.org/10.3102/0013189X10364671

Sheridan KM, Clark K, Williams A (2013) Designing games, designing roles: a study of youth agency in an urban informal education program. Urban Educ 48(5), 734-758. doi:10.1177/ 0042085913491220

Shin, S., \& Park, P. (2014). A Study on the Effect affecting Problem Solving Ability of Primary Students through the Scratch Programming. Accessed at http://onlinepresent.org/proceedings/vol59_2014/27.pdf. 
Sivaraj, R., Ellis, J. \& Roehrig, G. (2019). Conceptualizing the T in STEM: A Systematic Review. In K. Graziano (Ed.), Proceedings of Society for Information Technology \& Teacher Education International Conference (pp. 1245-1254). Las Vegas, NV, United States: Association for the Advancement of $\begin{array}{lllll}\text { Computing in } \quad \text { Education } & \text { (AACE). Retrieved }\end{array}$ from https://www.learntechlib.org/primary/p/207803/

Smith, B., \& Mader, J. (2017). Align your curriculum with the ISTE standards. The Science Teacher 84 (5), 8

Swaid, S. I. (2015). Bringing computational thinking to STEM education. ScienceDirect, 3, 3657-3682.

Taylor, M., Harlow, A., \& Forret, M. (2010). Using a computer programming environment and an interactive whiteboard to investigate some mathematical thinking. Procedia-Social and Behavioral Sciences, 8, 561570. doi:10.1016/j.sbspro.2010.12.078

Uçar, T. F. (2003). Visual communication and graphic design, Istanbul: Inkılap Bookstore.

Yenğin, D. (2010) Concept of violence in digital games: New violence. Marmara University, Institute of Social Sciences, Department of Communication Sciences, Doctoral Thesis.

Yükseltürk E. \& Altıok S. (2016). Pre-service information technology teachers` perceptions about using scratch tool in teaching programming. Mersin University Journal of Faculty of Education 12(1): 39-52. doi: http://dx.doi.org/10.17860/efd.94270

Yang, D. \& Baldwin, S.J. (2020). Using technology to support student learning in an integrated STEM learning environment. International Journal of Technology in Education and Science (IJTES), 4(1), 1-11.

Yünkül, Durak, Çankaya \& Misırlı (2017) The effects of scratch software on students' computational thinking skills. Necatibey Faculty of Education Electronic Journal of Science and Mathematics Education Vol. 11(2), 502-517.

Zhang, H., Yang, Y., Luan, H., Yang, S., \& Chua, T.-S. (2014). Start from Scratch. In Proceedings of the ACM International Conference on Multimedia - MM '14 (pp. 187-196). New York, New York, USA: ACM Press. http://doi.org/10.1145/2647868.2654915

\begin{tabular}{ll}
\hline & Author Information \\
\hline Ismail Donmez & Murat Tekce \\
Muş Alparslan University & $\begin{array}{l}\text { Ministry of National Education } \\
\text { Ankara/Turkey }\end{array}$ \\
$\begin{array}{l}\text { Muş/Turkey } \\
\text { Contact e-mail: i.donmez@ alparslan.edu.tr }\end{array}$ & \\
$\begin{array}{l}\text { Serihan Kirmit } \\
\text { Ministry of National Education } \\
\text { Ankara/Turkey }\end{array}$ & \\
\hline
\end{tabular}

